\title{
Gesto fotográfico e a produção de imagens-sensação sobre o Protocolo de Kyoto
}

Cristina Pontes Bonfiglioli

\section{Resumo}

A partir de uma seleção de imagens digitais, discute-se a relação entre a produção e observação de fotografias sobre o Protocolo de Kyoto e 0 discurso ecológico que o legitima. A discussão aborda as diferenças entre a operação de processos discursivos pautados eminentemente na escrita e na escritura, em relação à operação do processo fotográfico e da observação de fotografias. Estes últimos podem ser evidenciados como gestos com potencial de captar imagens-sensação.

\section{Palavras-chave}

Fotografia. Protocolo de Kyoto. Gesto fotográfico. Imagem fotográfica. Imagem-sensação.

\section{Cristina Pontes Bonfiglioli | khryz@usp.br}

Doutora em Ciências da Comunicação pela Escola de Comunicações e Artes da Universidade de São Paulo - ECA-USP. Desenvolve estudos de pós-doutorado no Núcleo de Estudos Filosóficos da Comunicação da ECA-USP.

\section{0 com-texto da imagem}

Suspeitamos que as imagens fotográficas - de origem mecânica ou digital, organizadas em grãos (fruto de reação química à luz, expressa na superfície opaca do papel) ou em pixels (resultado de relações lógico-matemáticas, expressas na superfície luminosa de uma tela) sejam fragmentos visuais de imagens do mundo tecnologicamente produzidos.

Uma imagem de mundo é uma representação de mundo ou mundivisão, marca da modernidade.

Tal qual entendida por Heidegger (1998), a imagem de mundo só é possível a partir da instauração, na Filosofia e na Ciência, da subjetividade cartesiana, e com ela, desse "novo" modo de operação intelectual/mental capaz de determinar a representação do mundo em função do clássico antagonismo sujeito-objeto. Essa maneira de "imaginar" o mundo e de pensá-lo, passa a ser dominante em todos os aspectos da elaboração e percepção humanas, sejam eles culturais, sociais ou históricos.

Só se chega à ciência como investigação se, e apenas se, a verdade se transformou em certeza 
do representar. É na metafísica de Descartes que 0 ente é, pela primeira vez, determinado como objetividade do representar. [...] Quando meditamos sobre a modernidade, perguntamos pela imagem do mundo moderna. Caracterizamo-la através de uma demarcação contra a imagem do mundo medieval e antiga. [...] 0 mundo está aqui como designação do ente na totalidade. 0 nome não está limitado ao cosmos, à natureza. Ao mundo pertence também a história. Mas mesmo a natureza e a história, e ambas no seu entrelaçamento recíproco, sobrepondo-se uma à outra, não esgotam o mundo. Nesta designação está co-implicado o fundamento do mundo, independentemente de como é pensada a sua referência ao mundo. [...] "Temos a imagem de algo" não quer apenas dizer que o ente nos é em geral representado, mas que ele, em tudo aquilo que Ihe pertence e que nele está reunido, está diante de nós como sistema. Em "ter a imagem" ressoa o estar-a-par, estar armado e preparado. [...] Imagem do mundo, compreendida essencialmente, não quer, por isso, dizer, imagem que se faz do mundo, mas o mundo concebido como imagem. [...] 0 que distingue a essência da modernidade não é que se transite de uma precedente imagem do mundo medieval para uma imagem do mundo moderna, mas sim que o mundo se torne, em geral, imagem. (HEIDEGGER, 1998, p. 110-113)

Para Heidegger, "pensar é re-presentar, referência representadora ao que é representado (idea enquanto perceptio)" (HEIDEGGER, 1998, p. 133) e o pensar "é algo certo que forma fundamento e dá fundamento":

0 que é certo é uma proposição que enuncia que ao mesmo tempo (ao mesmo tempo e com igual duração) com o pensar do homem ele próprio está indubitavelmente co-presente, isto é: está dado conjuntamente a si mesmo. (...) Re-presentar é ob-jectivação que avança, que doma. 0 representar empurra tudo para dentro da unidade do que é assim objetivo. 0 representar é coagitatio. (HEIDEGGER, 1998, pp. 114-115).

Nesse sentido, parece haver cruzamentos interessantes entre algumas noções do pensamento de Flusser e Heidegger, especialmente no que tange ao modo de operação do pensamento na modernidade, isto é, o papel da representação (como novo logos) na elaboração de mundividências (ou visões de mundo).

Representação, para Flusser (1983), é resultado de uma relação entre o Homem e os dados do mundo. Segundo o autor, o início da História não é apenas o momento da invenção, utilização e divulgação do alfabeto como nova técnica de representação, mas também a superação da hegemonia da técnica anterior, a das imagens em desenho, típicas do período préHistórico ${ }^{1}$. Flusser assume a representação como uma prática artística, que tem vínculo com a produção técnica de imagens e não com a "imaginação" científica, dependente de escritura (DERRIDA, 2005; 2006) e da relação sujeito-objeto clássica. Ainda que as

As primeiras evidências arqueológicas sobre a capacidade de expressão do ser humano são as imagens desenhadas nas cavernas de Rodésia, na África, de 40.000 a.C., de Lascaux e Chauvet na França, de 17.000 a.C., de Trois Frères e Le Gabilou, também na França, de 15.000 a.C., e de Altamira, na Espanha, datada de 14.000 a.C. bem como as dos principais sítios arqueológicos do Parque Nacional Serra da Capivara, no Piauí, datadas entre 12.000 e 6.000 a.C.. Todas essas inscrições, desenhos e pinturas, elaboradas na Idade da Pedra Lascada, mais precisamente no Paleolítico Superior (que vai de 25.000 a 5.000 a.C.), são manifestações consideradas por antropólogos e historiadores como o início da expressão artística humana e, portanto, dos primórdios de uma organização social e cultural. 
letras do alfabeto sejam 0 registro de imagens condensadas, miniaturizadas, sintetizadas, a linha - antes traço do desenho -, ao adquirir forma de letra, institui mais que uma etapa de substituição de modelos ou esquemas de troca de informação ou da comunicação entre os homens, mas a passagem de um processo de operação de pensamento para outro ${ }^{2} \mathrm{e}$ que independe da constituição de um método científico capaz de dar significação ao mundo.

É nesse recorte que, para Flusser (1983; 1985), a invenção da fotografia significa um processo semelhante e indica um novo regime do operar representações: a linha, que antes havia sido reduzida à constituição da letra, volta a se impor como forma, traço, volume, sombra, claro, escuro e, mais tarde, cor $^{3}$.

A esse retorno da imagem como forma de operação mental fundamental para se criar mundividências, Flusser denomina pósHistória (FLUSSER, 1983). 0 problema, aí, é que essa noção traz consigo o pressuposto de que as trocas culturais se dêem hoje mais intensamente por meio de técnicas de produção de imagens do que por meio de técnicas de produção de textos.
Porém, o que une textos e imagens continua sendo a noção de repraesentatio como forma de operação do pensamento. Independente de utilizarmos mais intensamente câmeras digitais inseridas em celulares para produzir fotografias ou teclados conectados a telas em cristal líquido para digitar textos, texto e imagem têm em comum esse fazer parte de mundividências, nas quais a lógica linear da escrita alfabética predomina.

0 fato de que as visões de mundo são dependentes de uma valoração do pensamento - o pensar "certo" - passa a constituir um papel relevante no desenvolvimento e na legitimação do próprio pensamento quando transposto para a escritura filosófica e científica. Para Heidegger (1998, p. 133-134), apenas 0 procedimento investigativo, característico da Ciência Moderna pode elaborar representações ou visões de mundo "corretas" e garantir um avanço do Homem em direção à certeza, à segurança, à liberdade como formas de culminar e atingir o Ser $($ Sein $)$.

Dessa forma, a noção heideggeriana de mundividência assemelha-se à noção foucaultiana de formação discursiva, já

Talvez seja por isso que Flusser (1983) não se preocupa em debater, conceituar ou definir a modernidade como período histórico, mas em discutir e explorar o modernismo como forma de expressão artística e cultural, em especial a antropofagia brasileira (BAITELLO Jr., 2006).

Até a primeira metade do século XIX, a Académie de Beaux-arts do Institut Français desdenhava o uso de cores vivas e pinceladas "pictóricas" [painterly] (típicos de Delacroix, por exemplo), "por serem tradicionalmente associados à "emoção" e à "sensibilidade", ambas consideradas "femininas" e destituídas de interesse teórico. Essa visão tinha suas raízes no debate acadêmico, iniciado no século XVII, sobre o valor relativo do dessin (que com freqüência era visto como expressão do controle "masculino") e da cor." (FRASCINA \& BLAKE, 1998). 
apontada por alguns autores (DELEUZE, 2005; GODZICH, 1994): há tantas visões de mundo quanto há discursos ${ }^{4}$. Os discursos referem-se à ordem do que é literal e alfabético, podendo, por isso, ter valor de lei - tanto aquelas explicitamente escritas, quanto as que são socialmente tácitas. Essa ordem do literal, ou da escritura, ainda separa o sujeito e a subjetividade do entorno, considerado "objetivo".

Assim, tanto a produção de imagens quanto a produção de textos, ambas realizadas por aparelhos $^{5}$ (FLUSSER, 1985), têm como referência primeira os discursos científicos (as certezas, como diria Heidegger) que as tornam possíveis como discursos técnicos. Os discursos técnicos - fotografia e texto - representam (sempre no sentido heideggeriano), por sua vez, outras camadas discursivas capazes de engendrar regimes de signos diversos. Nessas camadas mais superficiais ${ }^{6}$ de representação, esses regimes de signos têm por referência discursos estéticos (arte), políticos (poder), econômicos (dinheiro) ou afetivos (amor), agenciando sígnicas trocas coletivas.
São essas relações complexas entre as camadas [discursivas] de mundividências (mais superficiais), operadas por representações de discursos técnicos/técnico-científicos (mais basais $^{7}$ ) que constituem, ao nosso ver, os diferentes regimes de signos característicos de uma etapa que seria ainda anterior à profética pós-História flusseriana.

\section{Ato e gesto: camadas distintas da produção do fotográfico}

Dubois (2004) compreende o ato fotográfico como um processo que se inicia com o fotógrafo e termina no observador "final" da foto, em geral, exposta na parede de algum museu, já que a fotografia como Arte define em si mesma um valor final de obra enquanto tal. Porém, com a ampliação da presença da fotografia em inúmeros tipos de veículos de informação, há outros "espaços de exibição" que definem a legitimidade da imagem fotográfica como "verdade" artística ou "verdade" documental.

Flusser (1994), por sua vez, define o gesto fotográfico como parte de uma teoria geral dos gestos:

"If a worldview is a discursive construct, then it follows that there are as many worldviews possible as there are discourses. And if we bear in mind that for modernity worldviews and worlds tend to be identical, then there are as many possible worlds as there are discourses." (GODZICH, 1994, p. 362)

0 computador é, sem dúvida, a tecnologia que conseguiu reunir ambas as técnicas em um mesmo aparelho.

Superfície, aqui, como crítica da profundidade exposta por Michel Tournier: "Estranho preconceito, contudo, que valoriza cegamente a profundidade em detrimento da superfície e que pretende que superficial significa não de vasta dimensão, mas de pouca profundidade, enquanto que profundo significa ao contrário de grande profundidade e não de fraca superfície. E, entretanto, um sentimento como 0 amor mede-se bem melhor, ao que parece, se é que pode ser medido, pela importância de sua superfície do que pelo grau de profundidade..." (TOURNIER, s/a, p. 335-334 apud DELEUZE, 2003, p.12).

Basal, aqui, em oposição a superficial, para indicar posição e não valoração, tal como explicitado na nota anterior. 
Los gestos son movimientos del cuerpo que expresan uma intención. [...] Cuando levanto el brazo y alguien me explica que eso es el resultado de determinadas causas físicas, fisiológicas, psicológicas, sociales, económicas, culturales, etc., yo aceptaré su explicación. Mas no me sentiré satisfecho con ello. $Y$ es que estoy convencido de que levanto el brazo porque quiero y que, no obstante todas esas causas indudablemente reales, no lo levantaría si no quisiera. Por eso el levantamiento del brazo es un 'gesto'. El gesto es um movimiento del cuerpo, o de um instrumento unido a él, para el que no se da ninguna explicación causal satisfactoria. $Y$ defino asimismo lo de 'satisfatorio': en el discurso es el punto, que no necesita de ninguna discusión ulterior. (FLUSSER, 1994, p. 8)

0 gesto fotográfico, assim, é o gesto de movimento que o fotógrafo executa, munido de câmera fotográfica, "cercando" e buscando o momento do clique (ou momento decisivo, como denominou Cartier-Bresson ${ }^{8}$ ). 0 gesto fotográfico é, assim, o momento da produção de cada instantâneo, de cada fotograma. É a fotografia na duração (BERGSON, 1988). É a irrupção do inconsciente em seu contato com a intencionalidade do artista. Choque entre pulsão, atávica, inacessível, de morte ou de vida, e os discursos operatórios (FOUCAULT, 2005; GODZICH, 1994) que, no campo do racional (nem sempre consciente), orientam essa busca e essa movimentação do fotógrafo dentro da cena que pretende recortar da linha do tempo, em clique de congelamento.
0 gesto fotográfico opera, assim, o brinquedo (FLUSSER, 1983) como atualização de uma relação não percebida entre movimentos, decisões e escolhas conscientes e inconscientes, caracterizados, respectivamente, pela busca de elementos que serão recortados da cena e pelo automatismo da decisão do clique. 0 fotógrafo pode "afundar-se" tanto em um, quanto no outro. São opostos que interagem continuamente e que caracterizam o gesto fotográfico. 0 brincar com a câmera, como se fotografar fosse jogo (FLUSSER, 1983), se dá no gesto fotográfico. Na decisão pelo clique, se expressa, também, toda a responsabilidade de um ethos do gesto fotográfico.

A observação do fotograma produzido pelo gesto fotográfico é também gesto, mas de outra natureza, já que ele não dispõe de "clique". 0 gesto de observação pode levar, entretanto, a outro gesto fotográfico: ao avistar a imagem na tela de computador clica-se para "salvá-la" ou para transferila a um programa de edição de imagens fotográficas. Cada clique no teclado do computador é um gesto muito similar ao fotográfico: 0 "editor" busca evidenciar algo na imagem, quer alterá-la e, nesse movimento, dá continuidade ao ato fotográfico.

0 ato fotográfico deixa de ser, então, esse processo eminentemente restrito ao artístico como discurso (FOUCAULT, 2005) de validação 
estética e torna-se um "ecossistema ${ }^{9}$ de gestos".

Uma longa cadeia de gestos fotográficos em que os aparelhos (câmeras, celulares, computadores etc.) são brinquedos e executam programas, enquanto o fotógrafo/editor (profissional ou amador) de imagens executa "cliques", faz escolhas e publica a imagem em espaços de exibição não mais restritos à lógica do discurso estético.

Chamamos "ecossistema de gestos" porque os brinquedos produtores de gestos fotográficos aos quais nos referimos não podem disparar seus obturadores na ausência completa de dedos humanos. A relação dos dedos com os aparelhos é, também, exposta por Flusser:

[Os dedos] não se movimentam maquinalmente, embora se movimentem dentro e sobre várias "máquinas" (a de escrever, o alfabeto, a língua portuguesa). 0 seu movimento é deliberado, isto é, articula minha liberdade. [...] A cultura é natural para os dedos, e fora dela os dedos não são o que devem ser: livres. (FLUSSER, 1979, p. 65)

Essa combinação "olho-dedo-brinquedo" é a unidade mínima ${ }^{10}$ desse nosso ecossistema capaz de promover congelamento da cena no gesto fotográfico e paralização da temporalidade na qual o fotógrafo está imerso, ao mesmo tempo em que, no momento do gesto de observação do fotograma, a temporalidade parece movimentar-se em círculos: "eterno retorno", no dizer de Flusser.

Assim, a temporalidade do gesto fotográfico é o instante; a do gesto de observação é circular e a do ato fotográfico "tende ao infinito": uma vez "engolidos" pelos veículos de informação, os fotogramas "manipulados", perdem-se, afastamse (libertam-se?) do "registro" original do gesto e do tempo que os produziu.

0 ato fotográfico tornado infinito distancia cada vez mais o momento do primeiro clique, 0 clique óptico da unidade "olho-dedo-brinquedo" original. Nem mesmo noções como obturador e velocidade da captura da imagem têm, de fato, qualquer significação estática. Os programas tecnológicos digitais podem alterar essas concepções físicas do procedimento fotográfico analógico/mecânico. Esse brincar com a luz, as cores, as sombras, os traços e a nitidez da imagem fotográfica provoca "movimentos" no suposto congelamento de tempo tradicionalmente atribuído à imagem fotográfica.

Arthur George Tansley (1871-1955), ecólogo de plantas inglês, introduz a palavra e o conceito de ecossistema na apresentação de seu artigo The Use and Abuse of Vegetational Concepts and Terms na revista científica Ecology: "But the more fundamental conception is, as it seems to me, the whole system (in the sense of physics), including not only the organism-complex, but also the whole of physical factors forming what we call the environment of the biome - the habitat factors in the widest sense. It is the systems so formed which, from the point of view of the ecologist, are the basic units of nature on the face of the earth. These ecosystems, as we may call them, are of the most various kinds and sizes. They form one category of the multitudinous physical systems of the universe, which range from the universe as a whole down to the atom." (TANSLEY, 1935, p.299 apud GOLLEY, 1993, p. 8; grifo de TANSLEY, 1935)

Mesmo os satélites produtores de imagens precisam de programas para dispararem o obturador automaticamente: a decisão de dispará-lo não é gesto da máquina. Foi preciso que um dedo definisse em seu programa a freqüência de cada "clique". A fotografia por satélite seria um caso extremo de distanciamento entre o olho que vê, o dedo que clica e 0 brinquedo que registra. 
A partir do momento em que uma imagem da fotografia é gerada, o fotograma entra no processo ininterrupto de sucessão de gestos fotográficos e de observação. Assim, ao abrirmos o jornal, a revista, a página da Internet, não vemos o gesto fotográfico, mas o processo do ato fotográfico em andamento. 0 ato fotográfico opera o resultado do gesto fotográfico enquanto jogo e atualização no espaço de exibição de cada tipo de veículo de informação. 0 fotógrafo precisou percorrer o campo/cena em performance única de "olho-dedo-brinquedo" para selecionar os cortes, capturá-los em uma série de cliques que foram analisados na tela do computador ou no estúdio fotográfico. Os melhores resultados, na sua opinião, foram encaminhados a um fotógrafo em "outro nível da cadeia/ecosssitema de gestos" (editor de fotografia, agência de notícias, curador de exposição, juiz de concurso fotográfico etc), que, com sua "experiência" de "olho-dedo-brinquedo", realizou mais um gesto para decidir qual das imagens fotográficas iria ser exibida no espaço de legitimação de uma verdade documental ou estética.

Cada gesto de observação pode, assim, gerar um novo gesto fotográfico que a unidade "olho- dedo-brinquedo" opera. 0 gesto fotográfico é gesto inerente ao processo mais amplo do ato fotográfico. Para o fotojornalismo, entretanto, o momento do clique ou momento decisivo, é um gesto fotográfico complexo porque atende a uma expectativa, uma demanda, um uso potencial da imagem a ser "consumida" pelo ato fotográfico. Por isso, nunca há neutralidade no gesto fotográfico nem no ato fotográfico. Ambos estão imbuídos dos discursos técnicos, científicos, políticos, estéticos, jornalísticos que organizam a sociedade contemporânea e é nesse sentido que a fotografia representa (HEIDEGGER, 1998): um fotograma em pixels pode sempre tornar a ser gesto fotográfico e gesto de observação dentro do "ecossistema de gestos" e ter o seu "por-se em imagem" alterado, re-apresentado e re-presentificado. Gesto e ato fotográficos são, assim, a um só tempo, operadores e operados da/ na representação.

\section{Kyoto - discurso, texto e escritura}

0 Protocolo de Kyoto ${ }^{11}$ é um acordo internacional nascido de discussões e

Do ponto de vista da escritura do direito internacional, o Protocolo de Kyoto é uma Emenda ("amendment", em inglês) à Convenção-Quadro das Nações Unidas para as Mudanças Climáticas e, por isso, tem força de lei (é "legally binding", em inglês), diferente de Resoluções, que funcionam como recomendações e não produzem compromissos legais entre as partes envolvidas. Para entrar em vigor, o Protocolo precisou da ratificação de, pelo menos, 55 países, que passaram a ser listados no Anexo I (os países ou 'Partes' incluídas no Anexo I correspondem aos países-membros da OECD e aos países do antigo bloco soviético), cujas emissões de C02 somadas correspondiam a 55\% das emissões de gases estufa, em 1990, e que assumissem, também, o compromisso de reduzir as emissões nacionais em, no mínimo, 5,2\% em relação às emissões medidas naquele ano. Com a ratificação da Rússia, em 2004, a cláusula que exigia essas condições para o estabelecimento do vínculo legal do acordo foi satisfeita e 0 tratado pôde, então, entrar em vigor em 16 de fevereiro de 2005. A porcentagem de redução das emissões de C02 varia de acordo com o país industrializado listado no Anexo I do Protocolo e os países que não conseguirem atingir suas metas de redução até 2012 não sofrerão qualquer tipo de sanção. Por isso, o Protocolo de Kyoto foi considerado o "primeiro período de compromisso" dentro das negociações da ConvençãoQuadro da ONU. 0 próximo período inclui as decisões tomadas a partir de dezembro de 2008, na Polônia, e implicam em iniciativas para redução de emissões entre 2012 e 2020. Para acessar a versão integral, em português, do Protocolo de Kyoto visite: <http://www. mct.gov.br/index.php/content/view/28739.html>. Acesso em: 26 jun. 2008. 
negociações sobre a questão climática na $3^{\mathrm{a}}$

Conferência das Partes da Convenção-Quadro

das Nações Unidas sobre Mudanças Climáticas

\section{(UNFCCC - United Nations Framework}

Convention on Climate Change), realizada na

cidade de Kyoto, no Japão, em 1987. 0 acordo

conta, atualmente, com a ratificação de 175 países

e tem como objetivo o estabelecimento de metas

de redução de emissões de gases estufa ${ }^{12}$.

Central nas discussões ambientais atuais, 0

Protocolo de Kyoto é um texto que mobiliza

significações discursivas ao redor de algumas noções

que lhe são "fundantes": o principal gás estufa,

o dióxido de carbono, é emitido por processos

industriais que se utilizam de combustíveis fósseis

para gerar energia elétrica e trabalho mecânico,

e se acumula velozmente na atmosfera terrestre,

acelerando dramaticamente 0 efeito estufa.

Assim, o Protocolo de Kyoto representa

(HEIDEGGER, 1998) uma expectativa de

desenvolvimento e melhoria das condições

de vida, que, constituída discursivamente,

institucionaliza e atualiza o Projeto Moderno/

Iluminista pelo qual "igualdade, liberdade

e fraternidade" só podem ser alcançadas graças ao progresso humano, tecnológico e científico. A formação discursiva da qual faz parte - 0 discurso ecológico - propõe uma nova cidadania, entendida, agora, como "cidadania planetária". Estão postas, desta forma, tanto a crença na unidade Homem-Natureza e a coesão da Humanidade por um objeto comum - um sistema climático "sadio"-, quanto a primazia da escritura como único "método"/"processo" científico, filosófico e jurídico para se atingir esse arrojado projeto sócio-econômico cultural mundial. Reproduzindo e engendrados nessa situação, estão os veículos de informação que fazem circular, também, imagens fotográficas sobre esse modelo disciplinatório moderno.

No processo informativo no qual se enquadra 0 Protocolo de Kyoto, dois aspectos do percurso lógico-linear encadeiam-se. De um lado, a linearidade explicativa típica dos processos da escritura e do texto e do processo normativo do discurso ecológico, institucionalizado como formação discursiva. De outro lado, as significações sobre as relações causa-efeito características do pensamento lógico-dedutivo: as emissões de dióxido de carbono são responsáveis pelo aceleramento do aquecimento

Os gases do efeito estufa (GEE) são substâncias gasosas que absorvem parte da radiação infravermelha, emitida principalmente pela superfície terrestre, dificultando seu escape para o espaço e impedindo que ocorra uma perda demasiada de calor, o que mantém o planeta aquecido. Esse efeito de aquecimento, denominado "efeito estufa", é um fenômeno natural que ocorre desde a formação da Terra. Ele é fundamental para a manutenção da vida no planeta. Calcula-se que, sem ele, a temperatura média da Terra seria $33^{\circ} \mathrm{C}$ mais baixa, impossibilitando a vida como a conhecemos hoje. Entre os gases estufa, estão 0 dióxido de carbono (CO2), o metano ( $\mathrm{CH} 4$ ), o óxido nitroso (N20), perfluorcarbonos (PFCs) e também o vapor d'água. $0 \mathrm{CO2}$, $0 \mathrm{CH} 4$ e o N2O são os gases estufa mais importantes, uma vez que suas concentrações têm sido elevadas devido à ação antrópica. Os clorofluorcarbonos (CFCs) também têm a capacidade de reter a radiação infravermelha emitida pela Terra. Contudo, as ações para diminuir suas emissões [estabelecidas pelo Protocolo de Montreal] estão num estágio bem mais avançado, quando comparado com as emissões dos outros gases. Disponível em: <http://pt.wikipedia.org/wiki/Gases_do_efeito_estufa>. Acesso em: 10 mar. 2008. 
global que altera o padrão climático. Este, por sua vez, desorganiza os sistemas naturais e artificiais (incluídos os seres vivos que os compõem) que coexistem sobre a superfície do planeta, ameaçando sua sobrevivência/permanência. Esse "estado-daarte" consegue ser representado (HEIDEGGER, 1998) no espaço de legitimação da notícia por meio do texto jornalístico, mas será que, também, por meio das imagens que 0 acompanham?

Acreditamos que seja a insistência da escritura que dá significação ao fotojornalismo sobre o Protocolo de Kyoto. Porque inseridas em espaços discursivos - quer sejam estéticos (da parede do museu), quer noticiosos (do veículo de informação), todas as imagens fotográficas modernas dependem da escritura para significar ${ }^{13}$ :

[...] the putatively autonomous 'language of photography' is never free from the determinations of language itself. We rarely see a photograph in use which does not have a caption or a title, it is more usual to encounter photographs attached to long texts, or with copy superimposed over them. Even a photograph which has no actual writing on or around it is traversed by language when it is 'read' by a viewer (for example, an image which is predominantly dark in tone carries all the weight of signification that darkness has been given in social use; many of its interpretants will therefore be linguistic, as when we speak metaphorically of an unhappy person being 'gloomy'). (BURGIN, 1982, p. 144)

Assim, a legenda e os demais textos que acompanham como escritura as fotografias produzidas para o espaço da notícia, produzem uma imposição de significação à imagem, desde níveis mais "objetivos", como a presença de dêiticos ou de indicadores temporais e espaciais mais complexos, típicos da descrição noticiosa, até exposições mais analíticas.

Entendemos, então, que imagens estão cada vez mais dependentes de textos e a uma maneira de "interpretação" imposta pela lógica da "leitura" linear. A fruição, típica de processos artísticos, está subsumida pela penetração da estrutura e da lógica textual. É como se texto e imagem estivessem em constante conflito. Por isso, a proposta deste exercício de isolar as imagens de seus textos e contextos de origem, mantendo apenas o vínculo ao Protocolo de Kyoto como formação discursiva que motivou o gesto fotográfico de cada uma delas.

\section{A constituição das Séries sobre Kyoto}

As imagens alvo deste estudo são associadas ao Protocolo de Kyoto pelo próprio veículo de informação, seja ele portal de internet de agência de notícias; versão digital de jornal, revista ou informativo de ONG; website de agências governamentais e não-governamentais; website de fotógrafos envolvidos com a questão ambiental.

As fotografias digitais foram obtidas e selecionadas utilizando-se os mecanismos de

13 Nesse sentido, foi curiosa a atitude do site FreakyMartin.com que publicou, em 17 de janeiro de 2008, as 73 melhores fotos da MSNBC (Breaking World News and US News Stories and Headlines) sem incluir uma só legenda. A seqüência de fotos ganha um vetor de força único e desconcertante, porque nega a possibilidade de explicação/significação que a escritura impõe, quando legenda. Para ver as imagens, visite: <http://freakymartin.com/2008/01/17/the-best-photos-of-2007-msnbc-version-73-photos/>. 
busca Google e Google Images. ${ }^{14}$ A maioria das imagens relaciona-se ao período entre 2000 e 2007, quando ocorreram fatos importantes nas negociações e disputas políticas e econômicas em relação ao Protocolo de Kyoto. É nesse recorte diacrônico que se insere a saída dos Estados Unidos do processo de negociação, em 2000, e a ratificação do Protocolo pela Rússia, em 2004, o que garantiu sua entrada em vigor em 16 de fevereiro de 2005.

Nesse contexto, as fotografias que se produzem para "acompanhar" ou "ilustrar" a divulgação do Protocolo de Kyoto são dos mais variados tipos: retratos de políticos-chave para o processo de negociação (em especial Bush e Putin), proferindo discursos ou cumprimentando-se; líderes agrupados ao redor de mesas durante as Conferências das Partes organizadas pela ONU; grupos de ativistas em protestos; reuniões plenárias do IPCC ${ }^{15}$; florestas em chamas, enchentes, furacões, áreas desérticas ou o solo ressecado do leito de um rio que não existe mais.

As fotografias que nos interessam, no entanto, são aquelas que apresentam elementos em sua aparência que estão mais diretamente ligados às palavras do texto, ao contexto e às formações discursivas que operam o discurso ecológico e legitimam o Protocolo de Kyoto como um discurso sobre as mudanças climáticas. Esses elementos são: 1) o dióxido de carbono como causa, 2) o aquecimento global como efeito, 3) as fontes alternativas de energia como solução. Para cada um desses três grupos de elementos, que compõem a complexidade discursiva sobre o Protocolo de Kyoto, correlacionamos Séries de imagens fotográficas. As Séries baseiam-se na repetição, dentro da circularidade temporal de cada imagem, desses elementos componentes do discurso ecológico sobre Kyoto. Essa repetição foi considerada no processo de recorte, escolha e análise das imagens que se auto-definem como referências ao Protocolo.

Em primeiro lugar, as fotografias foram selecionadas considerando-se a indexação do Google Images ao se utilizar, no campo de busca, as seguintes palavras-chave: Protocolo de Kyoto; Kyoto Protocol; Mudanças Climáticas; Mudança do Clima; Alterações Climáticas;

0 Google (Google, Mountain View, CA, www.google.com) é o maior mecanismo de busca da Rede. Lançado em 1999, a indexação de páginas da Internet pelo Google chegou a mais de oito bilhões de documentos em 2005 - a contagem atualizada está sempre visível no pé da página principal do Google. 0 nome Google foi escolhido para representar a gigantesca quantidade de material disponível na Internet. 0 termo vem da palavra "googol" que representa o número 1 seguido por 100 zeros. 0 nome Google também é utilizado como verbo, em inglês: "to Google something" significa pesquisar algo na Internet utilizando-se do Google.

150 IPCC - Intergovernmental Panel on Climate Change (Painel Intergovernamental sobre Mudanças Climáticas) é um órgão científico que tem a tarefa de avaliar o risco das mudanças climáticas causadas pela atividade humana. Estabelecido em 1988 pela World Meteorological Organization - WMO (Organização Metereológica Mundial) e a United Nations Environment Programme - UNEP (Programa das Nações Unidas para Meio Ambiente - PNUMA), o IPCC não realiza pesquisas, nem monitora o clima ou fenômenos relacionados ao clima. A principal atividade do IPCC é publicar relatórios especiais sobre tópicos relevantes para a implementação da UN Framework Convention on Climate Change - UNFCCC (Convenção-Quadro das Nações Unidas sobre Mudanças Climáticas). Em 2007, o IPCC dividiu o Prêmio Nobel da Paz com o ex-Vice Presidente dos Estados Unidos, Al Gore. 


\section{Climate Change; Aquecimento Global;}

\section{Global Warming; Efeito Estufa; Greenhouse}

Effect. Obviamente, tais palavras-chave foram escolhidas considerando os elementos 1), 2) e 3) anteriormente mencionados. Essas relaç̧ões de causa-efeito são fundamentais à natureza das formações discursivas que constituem os agenciamentos ${ }^{16}$ de subjetividades ao redor da temática da sustentabilidade. Dessa forma, os elementos comuns a cada uma das séries "fazem lembrar" esse aspecto do discurso científico, que as fotografias por si mesmas não podem "dizer" nem "comprovar".

As imagens produzidas por fotojornalistas são utilizadas por diversos meios nacionais e internacionais eletrônicos e digitais para se referir diretamente ao Protocolo ou ao seu processo de negociação. A fotografia produzida para finalidades jornalísticas possui características mercantis peculiares ao sistema capitalista de produção da notícia. Elas são produzidas e distribuídas numa velocidade diária muito maior que qualquer outro tipo de fotografia. Não estamos mais na década de 30 do século passado, quando Dorothea Lange dependia de financiamento do governo e tinha apenas a possibilidade material de uma média de cinco a dez fotogramas por cena. A tecnologia permite que 0 fotógrafo passe de 1000 fotogramas utilizando-se de uma câmera digital reflex com memória flash ${ }^{17} \mathrm{e}$ ainda que ele "apague" resultados insatisfatórios no momento seguinte ao momento do clique. Assim, o fotógrafo vai "a campo" e, num recorte de tempo de algumas horas, pode clicar de uma a centenas de fotogramas, dependendo da cena (tema) que orienta seu gesto fotográfico do qual apenas um fotograma será selecionado para publicação no espaço de legitimação da notícia. As séries ${ }^{18}$ de fotografias construídas nesta pesquisa nasceram dessas constatações operatórias do fotojornalismo contemporâneo.

Diferente do discurso estético, que valoriza uma narrativa composta por vários cliques, 0 discurso da notícia prega o valor do spot news ou do breaking news. Um clique precisa

"Guattari e Rolnik (1996) definem agenciamento como uma "noção mais ampla do que a de estrutura, sistema, forma, etc. Um agenciamento comporta componentes heterogêneos, tanto de ordem biológica, quanto social, maquínica, gnosiológica, imaginária". (p. 317) Mais à frente, afirmam: "as máquinas, consideradas em suas evoluções históricas, constituem (...) um phylum comparável ao das espécies vivas. Elas engendram-se umas às outras, selecionam-se, eliminam-se, fazendo aparecer novas linhas de potencialidades. (...) no sentido lato (isto é, não só as máquinas teóricas, sociais, estéticas etc.), nunca funcionam isoladamente, mas por agregação ou por agenciamento. Uma máquina técnica, por exemplo, numa usina, está em interação com uma máquina social, uma máquina de formação, uma máquina de pesquisa, uma máquina etc." (p. 320)." (Guattari; Rolnik, 1996 apud HAESBAERT; BRUCE, 2004). Disponível em: <http://www.uff.br/geographia/rev_07/rogerio7.pdf>. Acesso em: 04 maio 2008.

Os novos cartões com tecnologia compact flash desenvolvidos para as câmeras reflex digitais são capazes de armazenar até 32 gigabytes de imagens em velocidades até 500 vezes superior à velocidade de uma máquina fotográfica analógica reflex.

Essa noção da série fotográfica é de tal forma importante para a análise do trabalho fotográfico em fotojornalismo que 0 achado da "mala mexicana" com os negativos de Robert Capa, em janeiro de 2008, foi tratado quase como descoberta arqueológica pelos Historiadores da Arte e da Fotografia Modernas. 
conter o máximo de elementos descritivos (e, portanto, lingüísticos) que se relacionem com a notícia. A expectativa é que o meio fotográfico seja capaz de sintetizar a notícia inteira em apenas um enquadramento. Daí a ação típica do fotógrafo: não basta um clique; é preciso uma quantidade maior para se ter certeza de que toda a informação que corresponde ao texto estará contida naquela imagem. Não à toa, 0 repórter fotográfico vai a campo com uma pauta já em mente. Sua fotografia é então "orientada" por um valor de notícia, além do estético.

Para a fotografia jornalística, entretanto, 0 discurso estético estaria em um segundo plano de importância ${ }^{19}$ quando comparado ao valor documental da imagem fotográfica.

0 exercício (também gesto) de observação das fotografias selecionadas é um percurso pelos diversos gestos fotográficos que buscaram caracterizar idéias ou noções a respeito da conexão entre 0 clima, a ação do Homem e os resultados sobre a performance alterada dos ciclos biogeoquímicos do planeta. Essa "miscigenação", entre as significações das palavras e os processos discursivos nos quais 0 gesto fotográfico estão inseridos, acaba sendo percebida pela maioria do público leigo como a constituição de noções sinônimas, muitas vezes por meio de "derivações metonímicas" que levam a equiparar lingüísticamente "Mudança Climática", "Aquecimento Global", "Efeito Estufa", "Protocolo de Kyoto" e "Poluição do Ar". Cada um dos fotogramas escolhidos é parte de uma sessão de gestos fotográficos cujo histórico não temos. Só temos acesso à parte do ato fotográfico que validou cada fotograma como exemplo de fotografia jornalística. Ao compor uma seleção de fotogramas, simulando a função de um curador ${ }^{20}$, propomos um novo gesto de busca (FLUSSER, 1994) que se distancia de métodos de pesquisa tradicionais, "forjando" ou "supondo" a sessão original por meio do registro do gesto que cada fotograma é. As séries correspondem a conjuntos de gestos fotográficos legitimados como notícia sobre a "temática da sustentabilidade" inscrita no Protocolo de Kyoto. Assim, a atividade de seleção de fotografias e organização das mesmas para os objetivos deste estudo, configura-se como expressão do ato fotográfico envolvido na produção, utilização e circulação de cada uma dessas imagens. 0 uso de fotogramas impressos nesta pesquisa não

Acumulam-se casos nas editorias de imagem das redações em que fotografias tiveram sua publicação negada porque apresentavam mais elementos estéticos do que propriamente valor de notícia. 0 que parece uma contradição tendo em vista os critérios subjetivos, em termos da combinação desses dois conjuntos de elementos complexos, mas supostamente opostos, e que entram em consideração nas premiações do Pulitzer, do World Press Photo Contest e do Robert Capa Gold Medal, para citar apenas alguns prêmios tradicionais de fotografia jornalística.

A curadoria é, também, um processo de criação, no qual o curador é "um agente cultural que trabalha para que as artes visuais criem um espaço público de reflexão sobre questões contemporâneas.” Disponível em: <http://forumpermanente.incubadora. fapesp.br/portal/.event_pres/workshops/folder.2005-06-20.3748870081/oficina_chus/>. Acesso em: 03 maio 2008. 
é somente gesto fotográfico, mas um gesto de busca que atualiza o processo infinito inerente ao ato fotográfico.

\section{As Séries: imagens-informação}

As fotografias que compõem as Séries constituídas para nosso estudo parecem repetir uma certa maneira de olhar e pensar a ilustração de Kyoto. Um primeiro grupo de imagens fotográficas parece representar, sistematicamente, a "causa" do Protocolo, ou seja, refere-se ao aumento das emissões antrópicas do dióxido de carbono, responsável pela aceleração do aquecimento do planeta, resultado do aumento de intensidade do Efeito Estufa. São fotografias que mostram engarrafamentos e chaminés, a que denominamos Série "Tubos".

Nessa Série, há a predominância pelo gesto fotográfico que buscou "ilustrar" o principal elemento constitutivo do discurso científico que institucionaliza Kyoto: 0 dióxido de carbono. Esse gesto fotográfico se dá pela preferência de cliques onde se vê emissão de fumaça/ poluição, como fumaça saindo de chaminés, de escapamento de carros, imagens de trânsito ou de engarrafamentos. É curioso notar que muitas dessas imagens trazem equívocos, como as que mostram torres de plantas geradoras de energia nuclear, que não emitem $\mathrm{CO}_{2}$ ou qualquer gás estufa (metano, óxido nitroso). As enormes nuvens brancas liberadas são formadas por vapor d'água. Do ponto de vista do Protocolo de Kyoto, uma usina nuclear produz energia "limpa" quando comparada às demais termelétricas a carvão, a óleo e a gás. É possível que a significação negativa (a relação direta entre energia nuclear e seus efeitos nocivos à saúde humana e ao meio ambiente) desse tipo de torre justifique seu uso para representar o Protocolo de Kyoto, apesar do equívoco de divulgação científica. Parece haver, também, um apelo estético dessas torres, com suas linhas curvas laterais e seu porte imponente.

Um segundo grupo de fotografias remete aos "efeitos" do aquecimento global, como o degelo dos pólos, dos glaciares, da neve permanente de cumes de montanhas, 0 aumento do nível do mar, o impacto do degelo sobre a vida selvagem nos pólos, 0 impacto do aquecimento sobre 0 solo e a água doce ou na distribuição e aparência das florestas e outras formações vegetais, denominada Série "Branca". Nela, as fotografias que "retratam" Kyoto mostram preferencialmente as regiões polares, ou áreas de estudo sobre o degelo, por isso a freqüência de imagens em que pedaços imensos de icebergs estão desprendendo-se ou onde há marcas claras de derretimento como grandes falhas e rachaduras que se mantêm sem se congelar há certo tempo, com o intuito de ilustrar e documentar as modificações sofridas nas áreas polares face ao aquecimento global.

Outras imagens, ainda, remetem às "soluções", ou seja, às fontes renováveis de energia - eólica, biomassa, solar. Entretanto, parece haver uma 
opção pelo registro das windfarms (fazendas eólicas) possivelmente pelo efeito estético dos hélices gigantescos, especialmente ao pôr-do-sol, a que denominamos Série "Girassóis".

Supomos, em todos esses casos, que, pelo fato de cada imagem fotográfica aparecer inicialmente acompanhada do texto da notícia (que, por sua vez, representa 0 espaço de exibição e de legitimação da verdade jornalística), todas as tecno-imagens podem estar diretamente relacionadas a um discurso científico, especificamente aquele que foi "pauta" do gesto fotográfico "autor" do fotograma. Por isso, as imagens das Séries podem ser consideradas "neutras" em termos de intencionalidade de significação e potencial de Sentido $^{21}$ e Sensação (DELEUZE, 2003; 2007). 0 hábito da interpretação da imagem pela lógica linear da escritura impõe a preponderância da "percepção" científica (lugar da significação), em detrimento da fruição sensível (possibilidade do Sentido e de Sensação). Ademais, sem um texto explicativo que identifique essas imagens e as relacione com o discurso ecológico motor do Protocolo de Kyoto, a "decodificação" não passa de um conjunto de associações genéricas com significados como "fumaça", "escapamento", "poluição", "vento", "energia eólica", "gelo", "Antártica", "Ártico", "urso polar".

Em todas as Séries percebe-se que o momento crucial da construção da significação sobre Kyoto se dá na ocasião de seu uso pelo veículo de informação, que necessariamente determina um vínculo racional entre os elementos presentes na imagem fotográfica e 0 texto escrito que a acompanha. Esse processo de escolha de texto e escolha de imagens - a edição -, enfim, reflete-se na maneira como a percepção pública se organiza em relação ao Protocolo de Kyoto.

\section{0 "fora" das Séries: imagens-sensação}

Deleuze (2007) desenvolve uma proposta para se pensar a imagem pictórica e a Sensação, a qual ele apresenta:

Há duas maneiras de ultrapassar a figuração (quer dizer, tanto 0 ilustrativo, quanto o narrativo): em direção à forma abstrata, ou em direção à Figura. Cézanne deu a essa via da Figura um

21 Ao longo deste trabalho, optou-se por utilizar a diferenciação entre os termos significação e Sentido, entendendo este último "como entidade não-existente" ou a expressão "do paradoxo das representações sem objeto" tal como proposto por Deleuze (2003): "No desenvolvimento de sua filosofia, após o livro Lógica do sentido, assistiremos a afirmação de que a filosofia é uma disciplina que trata da criação e invenção de conceitos. A tese de Deleuze é que o conceito remete ao acontecimento. Ora, procuraremos distinguir e compreender como se dá esta passagem do livro Lógica do sentido para o livro 0 que é a filosofia?. No primeiro, a questão do sentido está diretamente relacionada à proposição; já, no segundo, o sentido remete ao conceito. A idéia de acontecimento dá ao conceito um aspecto diferente daquele pensado por Aristóteles. Desta maneira, o pensamento de Deleuze procura apontar novas saídas para a filosofia. 0 nosso contacto com o mundo, dando-se através da superfície das coisas, nos faria apreender além das coisas, e suas imagens, os acontecimentos que as envolvem. Deleuze quer tornar relevante a idéia de que a linguagem e a superfície estão relacionadas. 0 que pensamos e falamos sobre as coisas passa pela superfície. 0 estatuto da idéia é superficial. A linguagem, somente atinge a significação quando se dá na superfície. A significação somente é possível pelo sentido que a envolve. 0 acontecimento sinaliza para o sentido como a proposição para a linguagem. 0 que deve ser esclarecido é que Deleuze aposta no conceito filosófico como incorporal. [...] 0 apreço de Deleuze por Lewis Carroll fá-lo afirmar que este, ao distinguir diferentes modos de tratar o sentido, sinaliza também para a diferença entre significação e sentido." (LOPEZ, 2003, p.205-206) 
nome simples: a sensação. A Figura é a forma sensível referida à sensação: ela age imediatamente sobre o sistema nervoso, que é carne, enquanto a Forma abstrata se dirige ao cérebro e age por intermédio do cérebro, mais próximo do osso. Cézanne certamente não inventou essa via da sensação na pintura, mas deu-lhe um estatuto sem precedentes. A sensação é 0 contrário do fácil e do lugar-comum, do clichê, mas também do "sensacional", do espontâneo etc. A sensação tem um lado voltado para 0 sujeito (o sistema nervoso, o movimento vital, o "instinto", o "temperamento", todo um vocabulário comum ao Naturalismo e a Cézanne) e um lado voltado para o objeto ("o fato", o lugar, 0 acontecimento). Ou melhor, ela não possui lados; ela é as duas coisas indissoluvelmente, é ser-no-mundo, como dizem os fenomenólogos: ao mesmo tempo eu me torno na sensação e alguma coisa acontece pela sensação, um pelo outro, um no outro ${ }^{22}$. Em última análise, é o mesmo corpo que dá e recebe sensação, que é tanto objeto quanto sujeito. Eu, como espectador, só experimento a sensação entrando no quadro, tendo acesso à unidade daquele que sente e do que é sentido. (DELEUZE, 2007, p. 42)

Acreditamos que o grupo de imagens

selecionadas e agrupadas como imagens-

sensação sejam "expressão" dessa definição de sensação. Todas elas parecem "desobedecer" às regras técnicas e discursivas que definiriam seu lugar como notícia nas páginas (impressas ou virtuais) de veículos de informação.

As três primeiras imagens fotográficas "parecemse" com a Série Tubos, as duas seguintes, do urso polar e dos corpos sobre 0 glaciar poderiam ser associadas à Série Branca, enquanto as duas últimas imagens poderiam ser juntadas à Série Girassóis. Entretanto, há elementos em cada um desses fotogramas, testemunhos dos gestos fotográficos que os produziram que os "impedem" de se relacionar com as Séries anteriores de maneira fácil e simples. São, definitivamente, imagens fotográficas que fogem ao clichê.

0 atrativo em cada uma dessas imagens é a confusão sensível que elas provocam e não sua capacidade explicativa. Há uma combinação de aspectos da forma e das cores ${ }^{23}$ que interpelam nosso corpo:

A lição de Cézanne vai além dos impressionistas: não é no jogo "livre" ou desencarnado da luz e da cor (impressões) que está a Sensação, mas no corpo, mesmo que no corpo de uma maçã. A cor está no corpo, a sensação está no corpo, e não no ar. A sensação é o que é pintado. 0 que está pintado no quadro é o corpo,

"Henri Maldiney, Regard, parole, espace, Lausanne, L’Âge d'Homme, p.136. Fenomenólogos como Maldiney ou MerleauPonty viram em Cézanne o pintor por excelência. Com efeito, eles analisam a sensação, ou melhor, "0 sentir", não apenas enquanto relaciona as qualidades sensíveis a um objeto identificável (momento figurativo), mas também à medida que cada qualidade constitui um campo que vale por si mesmo e interfere nos outros (momento "pático"). É esse aspecto da sensação que a fenomenologia de Hegel deixa de lado, e, no entanto, é a base de toda a estética possivel. Cf. Maurice Merleau-Ponty, Fenomenologia da Percepção, Paris, Gallimard. p.240-81; Henri Maldiney, op. cit., p.124- 208" (Nota da citação).

Até a primeira metade do século XIX, a Académie de BeauX-arts do Institut Français desdenhava o uso de cores vivas e pinceladas "pictóricas" [painterly] (típicos de Delacroix, por exemplo), "por serem tradicionalmente associados à "emoção" e à "sensibilidade", ambas consideradas "femininas" e destituídas de interesse teórico. Essa visão tinha suas raízes no debate acadêmico, iniciado no século XVII, sobre o valor relativo do dessin (que com freqüência era visto como expressão do controle "masculino") e da cor." (FRASCINA \& BLAKE, 1998, p. 61; itálico nosso)fapesp.br/portal/.event_pres/workshops/folder.2005-0620.3748870081/oficina_chus/>. Acesso em: 03 maio 2008. 
não enquanto representado como objeto, mas enquanto vivido como experimentando determinada sensação (o que Lawrence, falando de Cézanne, chamava de "0 ser maçanesco da maçã”) 24 (DELEUZE, 2007, p. 42-43).

Poder-se-ia dizer que as imagens selecionadas para compor esse conjunto são mais "complexas" em termos dos elementos visuais (ou dos signos) que remetem a muitos "referentes" ao mesmo tempo, quando, na verdade, a complexidade dessas imagens provém dos seus vetores de força que atualizam a sensação no observador. Ele é, de fato, obrigado a mergulhar nelas, a "perder tempo" em sua circularidade atemporal e se deixar aprisionar, se deixar levar, pela fruição sensível que elas evocam.

0 sistema "dedo-olho-brinquedo" que compõe o gesto fotográfico de cada imagem foi capaz de produzir combinações visuais que parecem escapar da escritura e do texto do Protocolo. Tais fotografias incorporam elementos imagéticos que constroem Figuras sobre Kyoto destacando a Sensação como principal vetor de força estética.

Eis o fio que liga Bacon a Cézanne: pintar a sensação, ou, como diz Bacon, usando palavras muito próximas das de Cézanne, registrar o fato. "É uma questão muito precisa, e difícil saber, por que uma pintura toca diretamente 0 sistema nervoso ${ }^{25}$. Quando Bacon fala da sensação, ele quer dizer duas coisas muito próxi- mas de Cézanne. Negativamente, ele diz que a forma referida à sensação (Figura) é o contrário da forma referida a um objeto que ela deveria representar (figuração). Segundo a expressão de Valéry, a sensação é o que se transmite diretamente, evitando o desvio ou o tédio de uma história a ser contada ${ }^{26}$. E, positivamente, Bacon não se cansa de dizer que a sensação é o que passa de uma "ordem" à outra, de um "nível" a outro. É por isso que a sensação é mestra deformações, agente de deformações do corpo. E, a esse respeito, pode-se fazer a mesma crítica à pintura figurativa e à pintura abstrata: elas passam pelo cérebro, não agem diretamente sobre o sistema nervoso, não têm acesso à sensação, não produzem a Figura, pois permanecem num mesmo nível. ${ }^{27}$ Elas podem operar transformações da forma, mas não atingem as deformações do corpo." (DELEUZE, 2007, p. 48-49, grifo do autor).

As imagens das Séries têm um vetor documental maior, ou um vetor de figuração: a referência delas é "0 objeto pensado, a coisa figurada". As "imagens-sensação", ao contrário, possuem "0 caráter irredutivelmente sintético da sensação" (DELEUZE, 2007, p.49).

0 urso assim, não é a figuração de um urso, não parece um urso pela posição "antropomorfizada" que assumiu no momento do clique. Parece simular a despreocupação e o relaxamento típicos dos humanos após um longo dia de trabalho. Onde está a ameaça de que tanto se fala? 0 urso tranqüilo parece desconhecer um destino já traçado.

24 D. H. Lawrence, Eros et les chien, "Introduction à ces peintures”, Paris, Bourgois. (Nota da citação).

Entrevistas I, p. 44. (Nota da citação.)

26 Entrevistas I, p. 122-3. (Nota da citação.)

27 Todos esses temas são constantes nas Entrevistas. (Nota da citação.) 
Os corpos humanos nus deitados sobre 0 gelo não são "apenas" corpos, mas extensões da paisagem. Uma intromissão, uma performance. A nudez da pele humana em contato com a aspereza do gelo frio. A Figura é a reconstrução da paisagem pela sensação, não mais pela "reprodução": um tapete vivo protege o gelo que, muito lentamente, se desfaz. 0 abraço metafórico que acaricia o planeta onde ele mais "sente dor".

0s hélices na neblina parecem margaridas e não girassóis. A imagem em preto e branco não documenta, evoca uma certa "aura", um recorte único e original, do gesto fotográfico. Outra "margarida" aparece "imponente", sob a neve, antítese do calor do sol. Nas imensas chaminés, as cores, linhas e sombras da fumaça e do vapor d'água em volumes diagonais no céu simulam 0 gesto de pintar a sensação, registrando o fato de maneira a causar deformações no corpo que efetiva o gesto de observação.

"Quando se fala da violência da pintura, isso nada tem a ver com a violência da guerra." ${ }^{28}$ À violência do representado (0 sensacional, 0 clichê) opõe-se a violência da sensação, que se identifica com sua ação direta sobre o sistema nervoso, os níveis pelos quais ela passa e os domínios que atravessa: sendo Figura, ela não deve nada à natureza de um objeto figurado. É como Artaud: a crueldade não é aquilo que se pensa e depende cada vez menos daquilo que é representado. (DELEUZE, 2007, p. 46).

\section{Gesto e representação; escritura e pós-História}

A fotografia sobre meio ambiente parece ser, tal qual a fotografia de guerra, um gesto fotográfico em direção à expressão do dano. Ambos os tipos de fotografia jornalística procuram se "alimentar" da necessidade do gesto fotográfico de se associar ao gesto de busca do fotógrafo, aquele gesto que legitima "a verdade" por estar, de alguma maneira, relacionado à escritura do discurso científico, ou seja, à representação heideggeriana: a visão do mundo em que a Ciência é empresa que opera a circulação dos signos "da verdade", dando a ver o próprio Homem.

Ao tentar compor "narrativas visuais" sobre o Protocolo de Kyoto, tenta-se "traduzir" na imagem fotográfica uma noção de tragédia iminente pela tentativa de se evidenciar na imagem significantes (e, portanto, "materialidades") que possam ser identificados, genericamente, como dor, sofrimento e perda.

Esse suposto apelo ao sentimento pelo uso de "referências" quase concretas aos elementos que "ameaçam" a vida humana, dá a impressão de que a percepção dessas imagens é imediata, como se o observador estivesse vivenciando o fato, como se seu olho fosse 0 olho do fotógrafo, a lente da câmera. É como se seu gesto de observação fosse capaz de reproduzir, de maneira idêntica, 
o gesto fotográfico da imagem que observa, estabelecendo uma cumplicidade na operação "olho-dedo-brinquedo" que veicula e legitima a força documental dessas imagens e que parece parodiar 0 velho ditado: "o que os olhos vêem, o coração sente".

Entretanto, o gesto de observação de imagens fotográficas parece operar, também, como um estado de clausura em que 0 observador se permite colocar. Um momento em que, paralisado na duração, instaura-se o choque entre experiência (Erfahlung) e vivência $(\text { Erlebnis })^{29}$, entre a lógica linear, ordenada e racional do texto - que legitima o Protocolo de Kyoto e o discurso ecológico no qual o Protocolo está engendrado - e a lógica circular, atemporal e sensória da imagem fotográfica. 0 observador parece encalacrado na operação técnica do texto, distinta da operação técnica da foto. No gesto de observação imiscui-se um gesto de busca que se expressa pela necessidade que o observador tem por uma explicação "racional" da imagem, capaz de "interpretar" ou de dar uma significação plausível para a fotografia que observa.

Nesse gesto de busca do observador, por sua vez, parecem coexistir ou alternar-se duas situações antagônicas. Em um momento, emerge a supremacia da ordem do texto, da palavra técnico-científica que dá significação ao Protocolo de Kyoto e viabiliza todas as remissões possíveis entre as diversas formações discursivas que constituem o discurso ecológico. Nessa situação, a imagem fotográfica, subjugada pela ordem da palavra falada mimetizada em escritura, terá o seu fruir relegado a segundo plano, e o que valida sua "leitura" será a racionalidade do texto. A imagem fotográfica perde sua força heurística, pois a operação de pensamento que poderia potencialmente engendrar é cooptada pela operação de pensamento fundado na linearidade, no princípio de causa-efeito, típico da lógica do texto.

Essa condição de supremacia do texto - ou seja, da explicação científica veiculada pelo discurso ecológico que embasa o Protocolo de Kyoto e impõe um valor maior do escritural sobre 0 da imagem -, passa a ser, em outro momento, transitória. Vemos, então, a vivência sobrepor-se à experiência, deixando-se levar pela fruição das cores, das linhas, das sombras, dos volumes e das formas na tecno-imagem. A sedução da imagem técnica vence a imposição da racionalidade linear e dá lugar ao fascínio e ao encantamento diante do inexprimível, do inexplicável, do que é pura vibração sensorial. Esse momento parece atuar de maneira mais notória no conjunto de imagens selecionadas como imagens-sensação.

"Segundo Dilthey, a vivência é algo revelado no "complexo anímico dado na experiência interna" ; é um modo de a realidade existir para um certo sujeito. A vivência não é, pois, algo dado; somos nós que penetramos no interior dela, que a possuímos de uma maneira imediata, podendo até dizer que ela e nós somos a mesma coisa. "A vivência", escreve Dilthey, "é um ser qualitativo: uma realidade que não pode ser definida pela captação interior, mas que alcança também o que não se possui indiscriminadamente (...) A vivência de algo exterior ou de um mundo exterior se encontra diante de mim de uma forma análoga àquilo que não é captado e que só pode ser inferido." (MORA, 2001, p. 3035). 
0 processo de deslizamento - equilíbrio/

desequilíbrio - de operações entre duas

lógicas de percepção e compreensão

distintas, relativas à vivência, caracteriza

agenciamentos de significações e de Sentidos,

que podem estabelecer relações sígnicas,

harmônicas ou desarmônicas, entre as

imagens fotográficas e o texto escrito que as

acompanha. Parece que, com maior freqüência,

o texto tenta acompanhar as imagens, dar-lhes

expressão e conteúdo, forjando um regime de

signos que é peculiar à linguagem, e não à

ordem imagética.

Nossas experiências visuais parecem sucumbir

a um modo de pensar todos os objetos como

"externos" ao pensamento, passíveis de

explicação racional exprimível apenas pela

linguagem: em pleno século 21 e a despeito

de toda a intensidade tecnológica e visual às

quais estamos submetidos diariamente, ainda

representamos o mundo pelo clássico viés

cartesiano, ou moderno, como diria Heidegger.

Entendemos que Flusser (1983), ao intuir esse

momento a que denominou pós-História, não

detalhou a extensão dessa etapa heteróclita, em

que a escala de produção do imagético é maior,

mas o modo de operação do pensamento ainda é

dominado pela escritura.
A argumentação de Flusser depende da dualidade de espaço e tempo. A fala tem a ver com sons, com música. Ela tem seu começo e seu fim. Ela se revela durante a linha temporal. Escrita, por outro lado, tem a ver com imagens, com pintura. Ela se reproduz no espaço vazio da página. Ao reduzir o lado pictórico da escrita para uma simples dimensão lógica da linha, Flusser, que de novo chama a si um dos principais pontos de Leroi-Gourhan, expõe todo um complexo mundial em inúmeras camadas que tem sido perdido. Isto pode ser sentido quando se lida com linguagens orientais que, neste respeito, são infinitamente mais sofisticadas. A subordinação da escrita sobre a palavra falada, então, como Flusser a coloca, tem paralisado nossas faculdades mentais e limitado nossa potencial criatividade. Uma crítica à escrita linear deveria ir além do aspecto temporal ao redescobrir 0 esquecido espaço dimensional da escrita, mais do que tudo, 0 campo bidimensional da página. Se nós vencêssemos as amarras da linearidade, que são conseqüência da predominância da palavra falada sobre a escrita, um modo completamente novo de pensamento poderia ser possível. (GULDIN, 2008, p.4, grifo nosso)

É importante salientar a necessidade de escapar da tendência clássica de valorar a lógica linear do texto escrito (e do discurso técnico-científico e racional que ele engendra) em detrimento da lógica circular, sensorial e irracional da tecnoimagem e vice-e-versa. Trata-se, novamente, de levantar as implicações geradas a partir de operações distintas e de se reconhecer que a segunda lógica continua em seus primórdios de exploraçãa ${ }^{30}$, especialmente na área acadêmica tradicional. Parece que há, sempre, discursos

Ainda que haja textos antológicos, no que tange à tentativa de ultrapassar a bidimensionalidade do papel e criar, pela escritura, o movimento e o fluxo constantes de um pensamento hipertextual, como no romance 0 Jogo da Amarelinha, de Cortázar, na poesia concreta de Haroldo de Campos (Galáxias), ou na escrita esquizóide da obra filosófica "0 Anti-édipo", de Deleuze e Guattari, o plano do papel e a linearidade da escritura continuam sendo um desafio para uma lógica que pretenda superar os limites da representação. 
amarrados escrituralmente e, portanto, representados enquanto possibilidades de certezas e de verdades e de visões subjetivas do mundo, costurando a produção, a observação e a percepção das tecno-imagens.

Por um lado, o texto escrito, enquanto legitimador do discurso racional, deixa claro quais são as formações discursivas em jogo, reforçando redundâncias de modos de olhar e de pensar. Por outro lado, as tecno-imagens inseridas em contextos teóricos de uso ou interpretação, parecem sucumbir à hegemonia da explicação, em detrimento da compreensão. Enquanto a primeira é entendida como processo de primazia do intelectual, a segunda dá primazia ao sentimento, ao modo de Dilthey (MORA, 2001). Assim, parece que a explicação é imposta às tecno-imagens pela lógica do racionalismo (filosófico e científico) dominante na escritura.

A tecno-imagem, às vezes percebida como cópia do real, às vezes interpretada como tendo a realidade como referência, esconde a dependência que temos de uma inteligibilidade predominantemente lingüística acerca dos fenômenos do mundo. Fascinados pelas cores e linhas, somos seduzidos não apenas do ponto de vista da "verdade", mas também, da referencialidade que é tão cara aos debates sobre imagens técnicas.
Há, de fato, um desconforto imediato no ver tecno-imagens que não se compreendem, mas são essas tecno-imagens que nos arrebatam, invadindo e vibrando, fazendo-nos corpo, e dessa forma, objeto delas. Nosso afã de buscar no texto a explicação que acalme a perturbação gerada,parece ser reflexo de uma certa necessidade de fuga, de distanciamento das imagens técnicas por meio da lógica linear do texto - única capaz de deter o ímpeto da Sensação e o potencial que as imagens têm de gritar "Eu!" e, dessa maneira, instaurarem-se como sujeitos que nos olham, como alerta Bredekamp ${ }^{31}$.

Talvez o pós-histórico ainda esteja por vir e será o momento em que as formas de representação centradas na verdade do eu que representa e nas operações do pensamento fundadas na escritura serão superadas. Texto e imagem continuarão a se inter-relacionar, se atrair e se repelir, mas haverá uma ruptura em relação à dependência interpretativa de um pensamento que opera segundo a linearidade de um racionalismo idealista, fruto de 25 séculos de filosofia.

Existe, ainda, uma dificuldade grande para discorrer, descrever, nomear ou explicar filosófica e cientificamente esses processos novos da relação e interação com o puramente imagético de maneira exclusivamente racional. A racionalidade como convenção de representações fundadas no sujeito cartesiano 
marca o positivismo e a modernidade, negando a possibilidade de se operar signos que dão relevância às afecções enquanto resultado de Sensação (DELEUZE, 2007), circular e corporal, e não de interpretação racional linear e contínua. Torna-se cada vez mais interessante resgatar o sensível e o sensório nos processos de trocas sígnicas, pois, como lembram Deleuze e Guattari (1997), "o conceito filosófico não se refere ao vivido, por compensação, mas consiste, por sua própria criação, em erigir um acontecimento que sobrevoe todo o vivido, bem como qualquer estado de coisas." (p.47) "Pintamos, esculpimos, compomos, escrevemos com sensações." (p. 216)

"Pensar é pensar por conceitos, ou então por funções, ou ainda por sensações, e um desses pensamentos não é melhor que 0 outro, mais completamente, mais sinteticamente 'pensado'." (p.254) "A sensação não é menos cérebro que o conceito". (p. 271, grifo nosso).

As imagens fotográficas comunicam pelas sensações que mobilizam no observador, mas essa "provocação" visual nada tem a ver com o peso social e psicológico do realismo no fotojornalismo e na fotografia. A "compreensão" racionalizada dos elementos ou o conteúdo de uma imagem podem dar-se pela "leitura" ou "interpretação" do que nela se inscreve como uma invasão ou imposição do texto, da escritura e da formação discursiva a que ela alude. Mas nem sempre 0 que nos comove conscientemente num produto cultural é o que nos comunica algo novo. Assim, não é o tema, nem a presença sígnica do dano como "referente", nem o caráter documental de denúncia que dispara o Sentido, mas o regime estético que pode operar o sensório e corporal, superando a violência da escritura para se transformar em violência da Sensação.

\section{Referências bibliográficas}

BERGSON, Henri. Ensaio sobre os dados imediatos da consciência. Lisboa: 70, 1988.

BREDEKAMP, Horst. Contra 'ilustrações': imagens como uma força ativa. In: SIMPÓSIO INTERNACIONAL CRISE DA IMAGEM OU CRISE DAS TEORIAS?, UNIFESP, 2008, São Paulo. Organizadores: Goethe Institut; UNIFESP; IA-Unicamp, FAU-USP; Fórum Permanente Museus de Arte entre o Público e 0 Privado, 2008. (Comunicação Pública)

BURGIN, Viktor. Looking at Photographs. In: Thinking photography. London: Palgrave;MacMillan, 1982. p. 142-153.

DELEUZE, Gilles. Francis Bacon: Lógica da Sensação. Rio de Janeiro: Jorge Zahar, 2007.

Lógica do sentido. São Paulo: Perspectiva, 2003.

DELEUZE, Gilles; GUATTARI, Félix. 0 que é a

Filosofia? Rio de Janeiro: 34, 1997.

DERRIDA, Jacques. A violência da letra: de Lévi-

Strauss a Rosseau. In: Gramatologia. São

Paulo: Perspectiva, 2006. p. 125-172.

Freud e a cena da escritura. In: . A

escritura e a diferença. São Paulo: Perspectiva, 2005. p. 179-227.

DUBOIS, Philippe. 0 ato fotográfico. Campinas: Papirus, 2004.

FLUSSER, Vilém. Los gestos: fenomenología y comunicación. Barcelona: Herder, 1994. 
Filosofia da caixa preta: ensaios para uma futura filosofia da fotografia. São Paulo: HUCITEC, 1985.

Pós-História: vinte instantâneos e um modo de usar. São Paulo: Duas Cidades, 1983.

Naturalmente: vários acessos ao significado de Natureza. São Paulo: Duas Cidades, 1979.

FOUCAULT, Michel. A arqueologia do saber. Rio de Janeiro: Forense Universitária, 2005.

FRASCINA, Francis; BLAKE, Nigel. As práticas modernas da arte e da modernidade. In: Modernidade e Modernismo: a pintura francesa no século XIX. São Paulo: Cosac \& Naify, 1998. p. 50-140.

GUATTARI, Felix e ROLNIK, Suely. Micropolítica: cartografias do desejo. Petrópolis: Vozes, 1996.

GODZICH, Wlad. Languages, images and the postmodern predicament. In: GUMBRECHT, Hans Ulrich; PFEIFFER, K. Ludwig. Materialities of Communication. Stanford: Stanford University Press, 1994. p. 355-370.

GOLLEY, Frank B. A history of ecosystem concept in ecology: more than the sum of the parts. New York: Yale University Press, 1993.

GUATTARI, Felix; ROLNIK, Sueli. Micropolítica: cartografias do desejo. Petrópolis: Vozes, 1996

GULDIN, Rainer. Derrida e Flusser: no conceito da escrita e o fim da linearidade. Revista Ghrebh, n. 11, mar. 2008. Disponível em: <http://www.revista.cisc. org.br/ghrebh/index.php/ghrebh/article/view/17/22> . Acesso em: 25 set. 2008

HAESBAERT, Rogério; BRUCE, Glauco. A desterritorialização na obra de Deleuze e Guattari. Revista GEOgraphia Programa de Pós-Graduação em Geografia, Universidade Federal Fluminense, Rio de Janeiro. N. 7, dez. 2004. Disponível em < http://www. uff.br/geographia/rev_07/rogerio7.pdf>. Acesso em: 04 maio 2008
HEIDEGGER, Martin. 0 tempo da imagem no mundo. In: Caminhos de floresta. Lisboa: Fundação

Calouste Gulbenkian, 1998. p. 95-138.

LOPEZ, Luiz Manoel. Teoria do sentido em Deleuze.

Anais de Filosofia. Revista da Pós-Graduação da Fundação de Ensino Superior de São João del-Rei (FUNREI), São João del-Rei, n. 10, p. 203-220, jul. 2003. Disponível em: <http://www.fe.unicamp.br/ dis/transversal/rizomas/luiz.pdf > . Acesso em: 03 mai. 2008 .

MORA, José Ferrater. Dicionário de Filosofia. São Paulo: Loyola, 2001.

BAITELLO JÚNIOR, Norval. Vilém Flusser e a terceira catástrofe do homem ou as dores do espaço, a fotografia e o vento. In: Flusser Studies. n. 03, nov. 2006. Disponível em: <http://www.flusserstudies.net/ pag/03/terceira-catastrofe-homem.pdf>. Acesso em: 25 set. 2008 .

PRICE, Derrick. Surveyors and surveyed: photography out and about. . In: WELLS, Liz (ed.). Photography: a critical introduction. New York: Routledge, 2000. p. $65-115$. 


\section{¿ecompós}

www.e-compos.org.br

| E-ISSN 1808-2599 |

Série Tubos
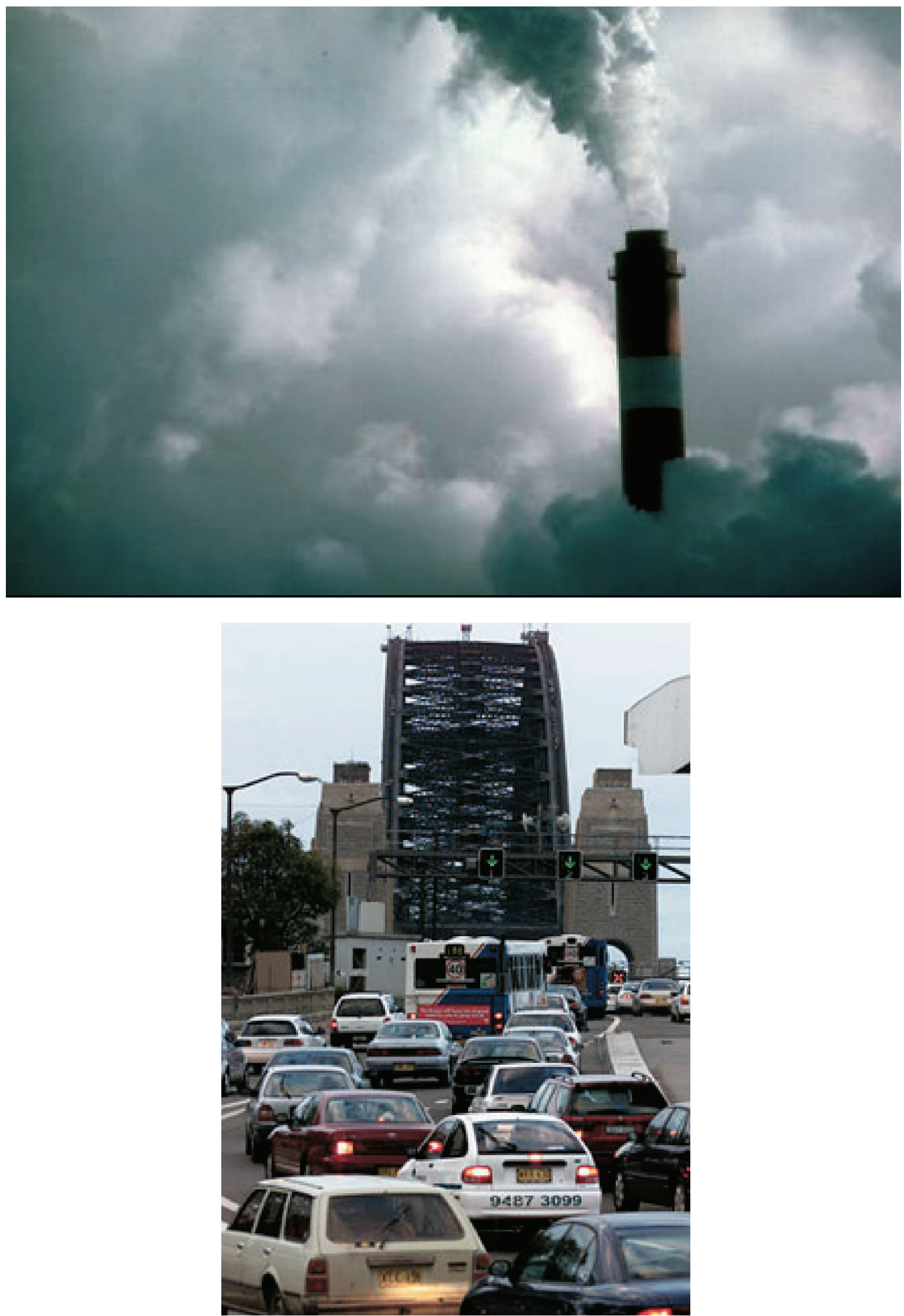

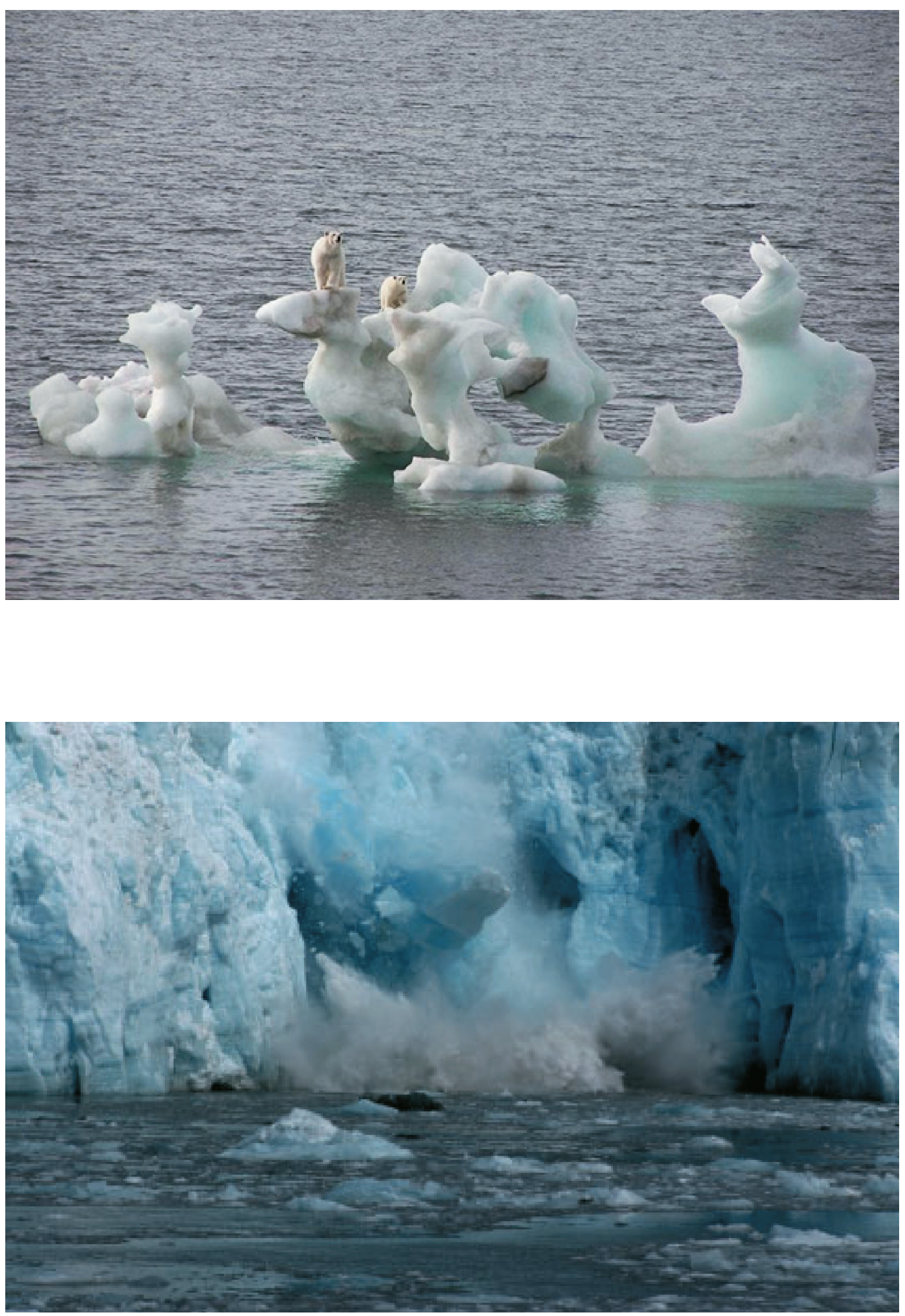
¿ compós

www.e-compos.org.br

| E-ISSN 1808-2599 |

Série Girassóis
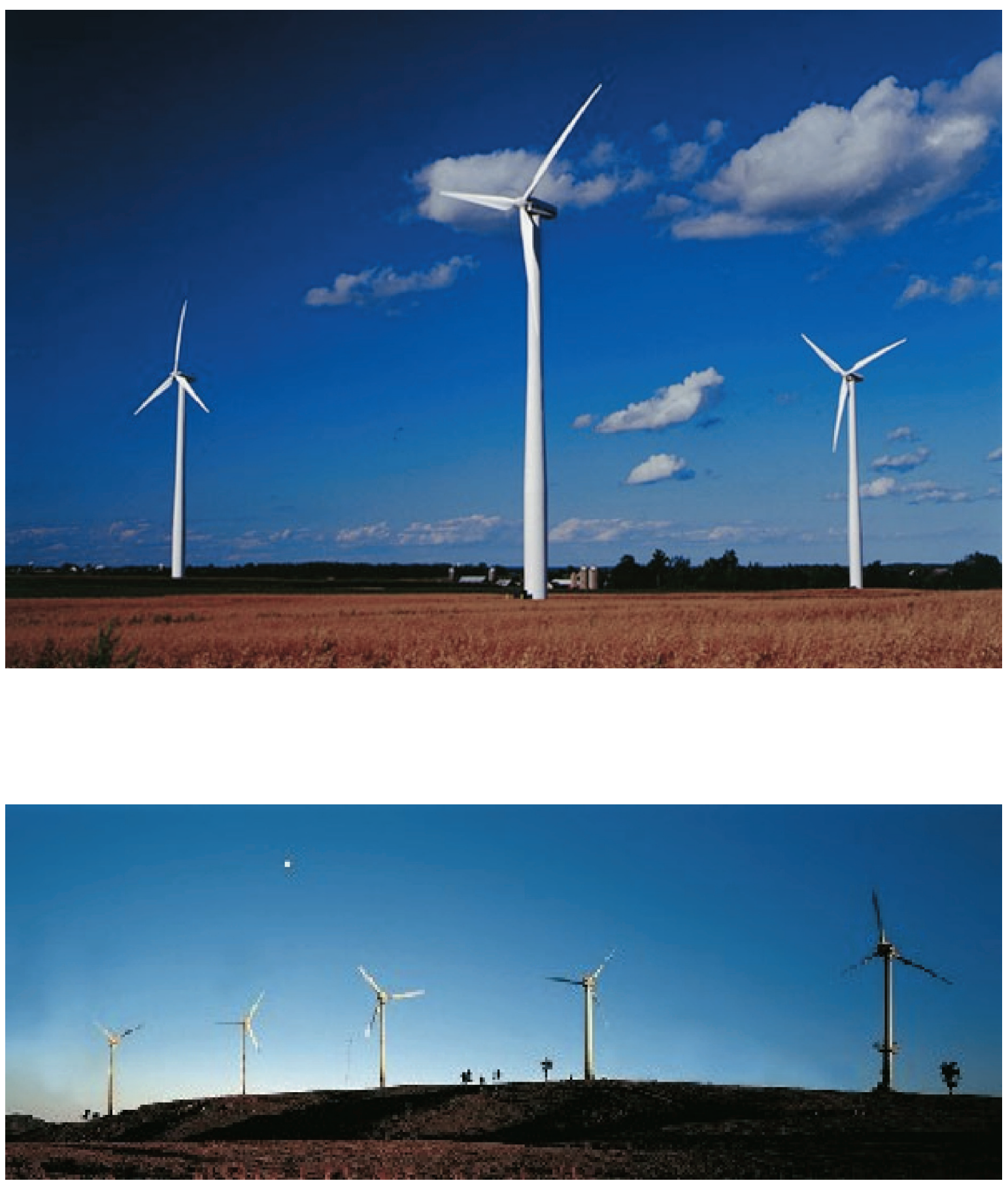

望 

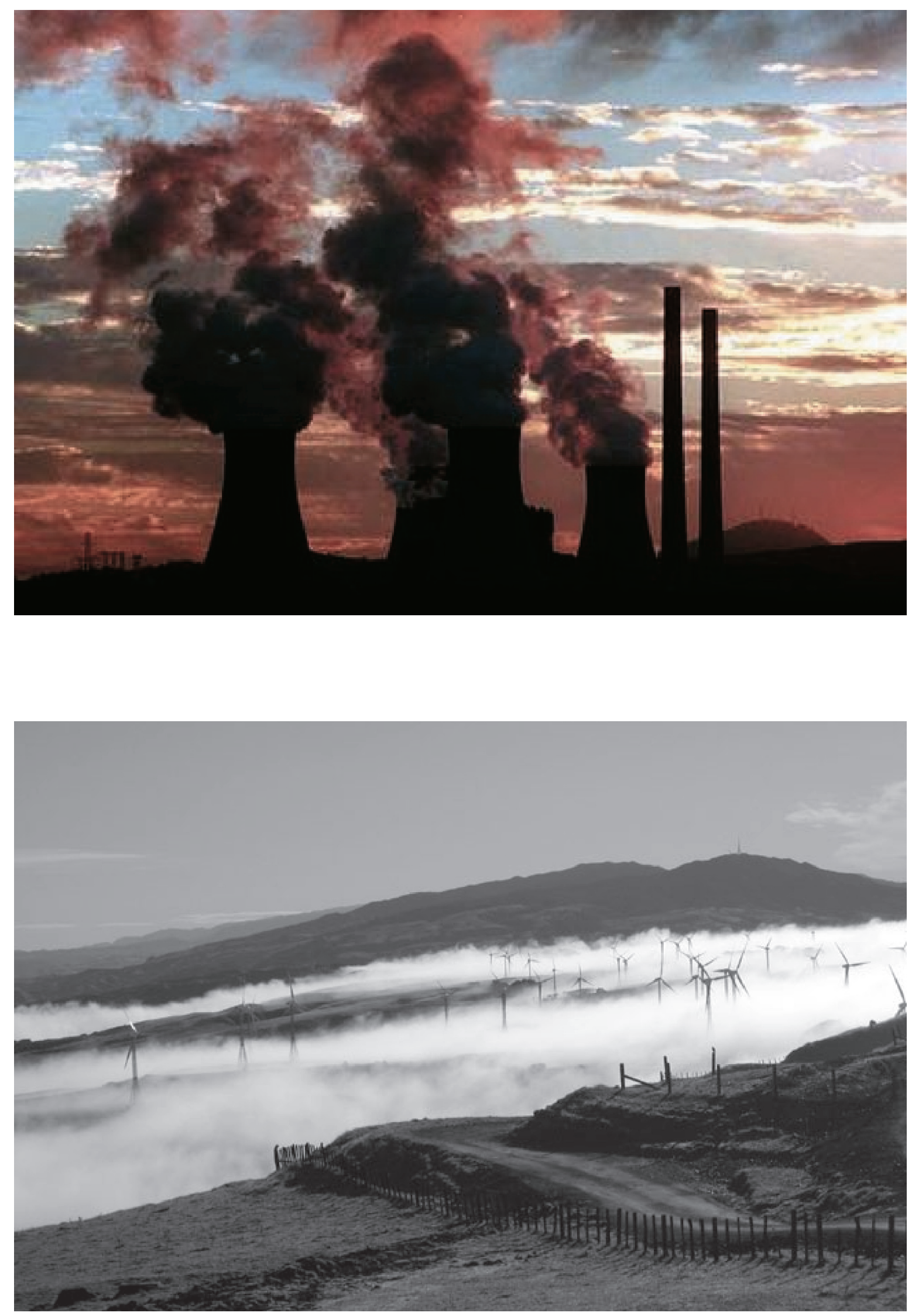


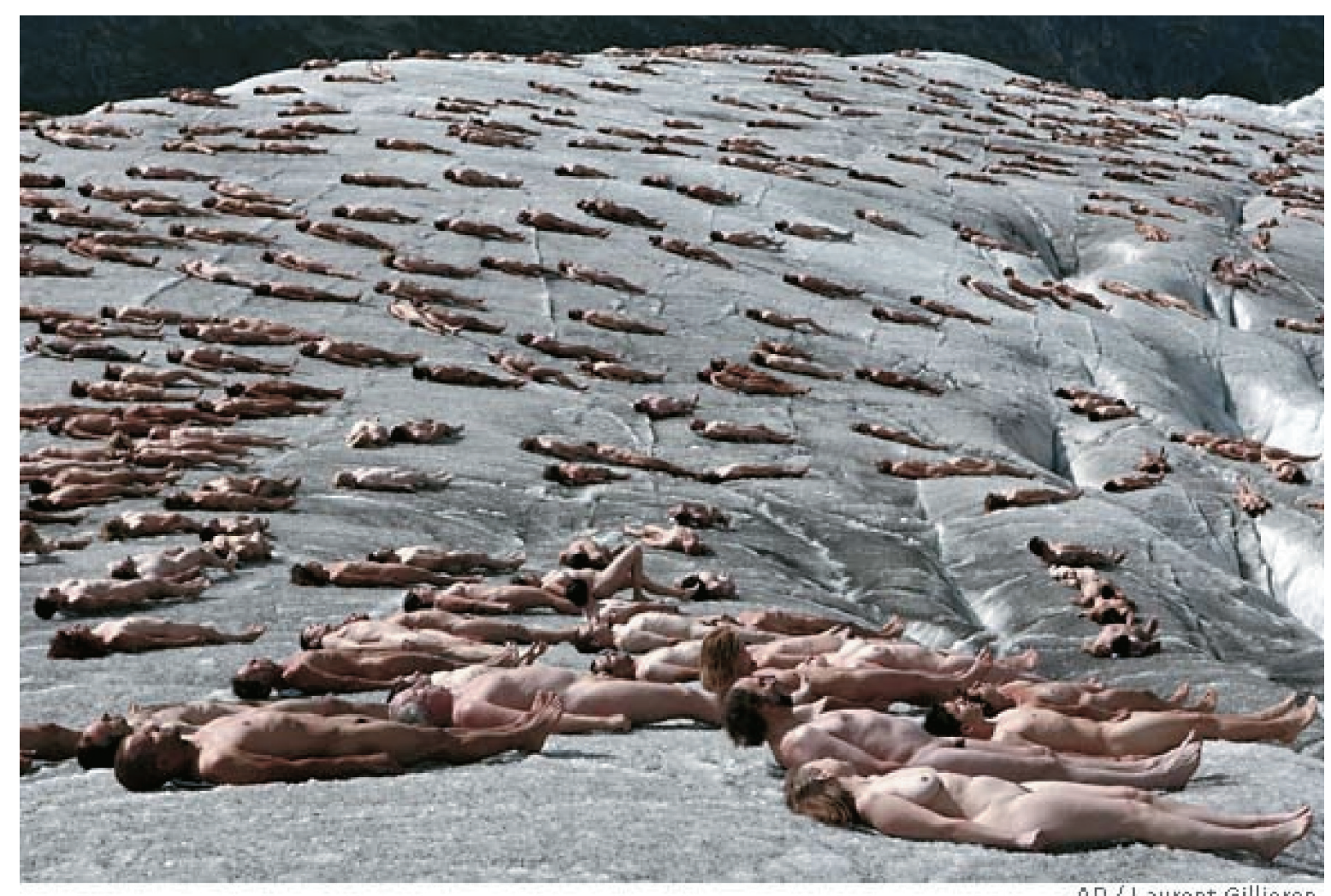

AP I Laurent Gillieron

\section{URLs das imagens analisadas}

Obs.: Todas as imagens foram acessadas pelo menos uma vez, desde agosto de 2005, mas assinalamos, aqui, a data do último acesso que confirmou a permanência das imagens nas referidas URLs.

\section{Série Tubos}

Figura 1

Disponível em: <http://english.pravda.ru/img/2005/07/ kyoto_protocol.jpg >

e <http://climatechange.sea.ca/smoke_stack.jpg >

e $<$ http:/www.oneclimate.net/imagelib/

posts/20070427/is2p2.jpg>

Acesso em: 15 abr. 2008.

Figura 2

Disponível em: <http://www.theepochtimes.com/ news_images/2005-2-18-greenhouse.jpg> Acesso em: 15 abr. 2008.

\section{Série Branca}

Figura 3

Disponível em: < http://www.instablogsimages.com/ images/2007/11/28/melting-glaciers_7548.jpg< Acesso em: 15 abr. 2008.

Figura 4

Disponível em: <http://www.undispatch.com/pola\%20 bears.jpg>

Acesso em: 15 abr. 2008.

\section{Série Girassóis}

Figura 8

Disponível em: < http://www.climateforchange.ca/files/ climateforchange.ca/imce_images/HomePageGraphicbackground.jpg $>$

Acesso em: 15 abr. 2008. 
Figura 6

Disponível em: <http://www.sutton.gov.uk/

NR/rdonlyres/BE6BC4D7-96F2-429A-8E79-

3FD3E28AEEEB/0/whatisbeingdonenationally1.jpg $>$

Acesso em: 15 abr. 2008.

\section{Imagens-sensação}

\section{Figura 7}

Disponível em: <http://www.smh.com.

au/ffximage/2005/02/16/climatechange

wideweb_430x323.jpg >

$\mathrm{e}<\mathrm{http}$ //www.education.theage.com.au/userimages/

issu101104.jpg $>$

Acesso em: 15 abr. 2008.

Figura 8

Disponível em: <http://www.windenergy.org.nz/photos/ gallery/tararua2/040727-NZ-TararuaB\&WMist.jpg>

Acesso em: 15 abr. 2008.

Figura 9

Disponível em: <http://www.sfgate.com/c/

pictures/2007/08/19/mn_spencer_tunick_ale107.jpg $>$

Acesso em: 15 abr. 2008 
Photographic gesture and the production of sensation-images on Kyoto Protocol

\section{Abstract}

From a selection of digital images, this paper discusses the relation between the production and observation of photographs about the Kyoto Protocol and the ecological discourse, which legitimates it. The approach addresses the differences between the operation of discursive processes driven eminently by writing (in Derrida's meaning), and both the photographic process and the observation of photography. These processes can be highlighted as gestures with the potential to capture sensation-images.

\section{Keywords}

Photography. Kyoto Protocol. Photographic gesture. Photographic image. Sensation-image.

\section{Gesto fotográfico y la producción de imágenes-sensación sobre el Protocolo de Kyoto}

\section{Resumen}

Desde una selección de imágenes digitales, se discute la relación entre la producción y la observación de fotografías sobre el Protocolo de Kyoto y el discurso ecológico que lo legitima. La discusión aborda las diferencias entre las operaciones de los procesos discursivos pautados eminentemente en la escrita y en la escritura, y el proceso fotográfico y de observación de fotografías. Estos últimos son procesos que se evidencian como gestos con potencial de capturar imágenes-sensación.

\section{Palabras clave}

Fotografía. Protocolo de Kyoto. Gesto fotográfico. Imagen fotográfica. Imagen-sensación. 


\section{Expediente}

A revista E-Compós é a publicação científica em formato eletrônico da Associação Nacional dos Programas de Pós-Graduação em Comunicação (Compós). Lançada em 2004, tem como principal finalidade difundir a produção acadêmica de pesquisadores da área de Comunicação, inseridos em instituições do Brasil e do exterior.
E-COMPÓS I www.e-compos.org.br I E-ISSN 1808-2599

Revista da Associação Nacional dos Programas de Pós-Graduação em Comunicação. Brasília, v.11, n.2, maio/ago. 2008.

A identificação das edições, a partir de 2008 passa a ser volume anual com três números.

\section{CONSELHO EDITORIAL}

\section{Afonso Albuquerque}

Universidade Federal Fluminense, Brasil

Alberto Carlos Augusto Klein

Universidade Estadual de Londrina, Brasi

Alex Fernando Teixeira Primo

Universidade Federal do Rio Grande do Sul, Brasi

Alfredo Vizeu

Universidade Federal de Pernambuco, Brasil

Ana Carolina Damboriarena Escosteguy

Pontifícia Universidade Católica do Rio Grande do Sul, Brasil

Ana Silvia Lopes Davi Médola

Universidade Estadual Paulista, Brasil

André Luiz Martins Lemos

Universidade Federal da Bahia, Brasil

Ângela Freire Prysthon

Universidade Federal de Pernambuco, Brasi

Antônio Fausto Neto

Universidade do Vale do Rio dos Sinos, Brasil

Antonio Carlos Hohlfeldt

Pontifícia Universidade Católica do Rio Grande do Sul, Brasil

Arlindo Ribeiro Machado

Universidade de São Paulo, Brasil

César Geraldo Guimarães

Universidade Federal de Minas Gerais, Brasi

Cristiane Freitas Gutfreind

Pontifícia Universidade Católica do Rio Grande do Sul, Brasi

Denilson Lopes

Universidade Federal do Rio de Janeiro, Brasil

Eduardo Peñuela Cañizal

Universidade Paulista, Brasil

Erick Felinto de Oliveira

Universidade do Estado do Rio de Janeiro, Brasil

Francisco Menezes Martins

Universidade Tuiuti do Paraná, Brasil

Gelson Santana

Universidade Anhembi/Morumbi, Brasi

Hector Ospina

Universidad de Manizales, Colômbia

leda Tucherman

Universidade Federal do Rio de Janeiro, Brasil

Itania Maria Mota Gomes

Universidade Federal da Bahia, Brasil

Janice Caiafa

Universidade Federal do Rio de Janeiro, Brasil

Jeder Silveira Janotti Junior

Universidade Federal da Bahia, Brasil
John DH Downing

University of Texas at Austin, Estados Unidos

José Luiz Aidar Prado

Pontifícia Universidade Católica de São Paulo, Brasil

José Luiz Warren Jardim Gomes Braga

Universidade do Vale do Rio dos Sinos, Brasi

Juremir Machado da Silva

Pontifícia Universidade Católica do Rio Grande do Sul, Brasil

Lorraine Leu

University of Bristol, Grã-Bretanha

Luiz Claudio Martino

Universidade de Brasília, Brasil

Maria Immacolata Vassallo de Lopes

Universidade de São Paulo, Brasil

Maria Lucia Santaella

Pontifícia Universidade Católica de São Paulo, Brasil

Mauro Pereira Porto

Tulane University, Estados Unidos

Muniz Sodre de Araujo Cabral

Universidade Federal do Rio de Janeiro, Brasil

Nilda Aparecida Jacks

Universidade Federal do Rio Grande do Sul, Brasil

Paulo Roberto Gibaldi Vaz

Universidade Federal do Rio de Janeiro, Brasil

Renato Cordeiro Gomes

Pontifícia Universidade Católica do Rio de Janeiro, Brasil

Ronaldo George Helal

Universidade do Estado do Rio de Janeiro, Brasil

Rosana de Lima Soares

Universidade de São Paulo, Brasil

Rossana Reguillo

Instituto Tecnológico y de Estudios Superiores do Occidente, México

Rousiley Celi Moreira Maia

Universidade Federal de Minas Gerais, Brasil

Sebastião Carlos de Morais Squirra

Universidade Metodista de São Paulo, Brasil

Simone Maria Andrade Pereira de Sá

Universidade Federal Fluminense, Brasil

Suzete Venturelli

Universidade de Brasília, Brasil

Valério Cruz Brittos

Universidade do Vale do Rio dos Sinos, Brasil

Veneza Mayora Ronsini

Universidade Federal de Santa Maria, Brasil

Vera Regina Veiga França

Universidade Federal de Minas Gerais, Brasil
COMISSÃO EDITORIAL

Ana Gruszynski I Universidade Federal do Rio Grande do Sul, Brasil João Freire Filho I Universidade Federal do Rio de Janeiro, Brasil Rose Melo Rocha I Escola Superior de Propaganda e Marketing, Brasil

\section{CONSULTORES AD HOC}

Aníbal Bragança I Universidade Federal Fluminense, Brasil Gisela Castro I Escola Superior de Propaganda e Marketing, Brasil

Gislene Silva I Universidade Federal de Santa Catarina, Brasil

Maria Helena Weber I Universidade Federal do Rio Grande do Sul, Brasil

Rosana de Lima Soares I Universidade de São Paulo, Brasil

Tania Hoff I Escola Superior de Propaganda e Marketing, Brasil

REVISÃO DE TEXTO E TRADUÇÃo I Everton Cardoso

ASSISTÊNCIA EDITORIAL E EDITORAÇÃO ELETRÔNICA I Raquel Castedo
COMPÓS I www.compos.org.br

Associação Nacional dos Programas de Pós-Graduação em Comunicação

Presidente

Erick Felinto de Oliveira

Universidade do Estado do Rio de Janeiro, Brasil erickfelinto@uol.com.br

Vice-presidente

Ana Silvia Lopes Davi Médola

Universidade Estadual Paulista, Brasil

asilvia@faac.unesp.br

Secretária-Geral

Denize Correa Araújo

Universidade Tuiuti do Paraná, Brasil

denizearaujo@hotmail.com 